\title{
Risk-sensitive foraging strategy of flower visitors in Serjania caracasana
}

\author{
Ana Paula Jejesky de Oliveira ${ }^{1}$, Juliétty Angioletti Tesch ${ }^{1}$, Giuliano de Matin ${ }^{1}$, Fernanda \\ Pavesi Tanure ${ }^{1}$, João Luiz Rossi Junio ${ }^{\mathrm{r} 1}$, Ary Gomes da Silva ${ }^{2}$. \\ 1 University Vila Velha. Avenue Comissário José Dantas de Melo, n 21, Boa Vista, Vila Velha, Espirito Santo, Brazil. \\ 2 Capixaba Institute for Research, Technical Assistance and Rural Extension. Afonso Sarlo Street, 160, Bento Ferreira, Vitória, Espirito \\ Santo, Brazil. \\ Corresponding author: MSc. Ana Paula Jejesky de Oliveira. anapaulaoliveira799@yahoo.com.br \\ https://orcid.org/0000-0003-2933-9764, https://orcid.org/0000-0002-0537-9123, https://orcid.org/0000- \\ 0002-1485-8214, https:// orcid.org/0000-0001-8252-4446,https://orcid.org/0000-0003-4374-378X, \\ https://orcid.org/0000-0003-3079-7316
}

Keywords: foraging, insect, nectar, floral visitors.

Publication date 30/11/2019, http://www.m.elewa.org/JAPS

\section{ABSTRACT}

Production of nectar can play a fundamental role in the foraging behaviour of floral visitors through its availability and distribution. The aim of this study was to understand the foraging pattern of floral visitors in Serjania caracasana. The field study observed the strategy of nectar production and the foraging behaviour of the floral visitors of Serjania caracasana, carried out through an experiment that evaluated the amount of nectar produced by flowers, species richness and frequency of visits. The data analysis showed that there is no significant correlation between any of the variables analysed. The unstable nectar between the flowers and the unpredictability during the hours of the day suggest a risk-foraging strategy of risk-prone type of the species of floral visitors. The data from this study suggests that Serjania caracasana has potential to understand the theory of risksensitive foraging in relation to its reproductive success.

\section{INTRODUCTION}

The energetic reward of different floral species has enormous influence on the foraging behaviour of pollinating animals. This insectplant interaction is a dynamic system that presents variation both in plant strategy and in the behaviour of flower visitors (Pyke 2016; Richman et al. 2017). This relationship encompasses a high variety of consumption and resource networks (Lange et al. 2013), in which the secretion of nectar may vary depending on location, time, age and flower size and / or environmental conditions (Zimmerman and Pyke 1988; Sazima et al. 1994; Vicentini and Fischer 1999). Thus, the availability and distribution of nectar among flowers can determine the behaviour of pollinators in relation to the frequency of visits, the number of flowers visited and the duration of the visit (Rathcke 1992; Pyke 2016). Flowers of the same plant tend to be similar in their production rate, concentration and composition of the nectar. This reflects on the behaviour of the floral visitor, who estimates the time and nectar removed since the last poll and expects the yield of nectar from another flower on the same plant to be similar to the last flower visited. From there, they use this information to make decisions that improve their foraging success. This theory is called optimal foraging (Pyke 2010; Pyke 2016). In the theory of optimal foraging there is a balance between the costs and benefits of these behavioural 
decisions. In this hypothesis individuals seek to maximize food intake or decrease foraging time (Ricklefs 2009). That is, the floral visitor continues to take nectar from one flower until the net rate of energy consumption falls and then probably moves to another flower on the same plant with increasing amounts of energy obtained in the current flower (Hodges and Wolf 1981). However, it is worth remembering that in addition to the average nectar or energetic return (nutritional questions), the variation of the resource distribution over this

\section{MATERIAL AND METHODS}

3.1 Study area: The study was developed in Vale Natural Reserve, in Linhares - ES with an area of 22,711ha, associated to the Reserva Biológica de Sooretama (RBS). The reserve is managed by the Instituto Chico Mendes de Conservação da Biodiversidade (ICMBio), and together with the two Private Reserves of Natural Heritage owned by FIBRIA, it forms a continuous block of protected forest with approximately 50,000ha. Within the reserve four major types of plant physiognomy are found. The highest forest, Mata Alta, is characterized by high-altitude trees, which reach more than $35 \mathrm{~m}$, and by clay soils (Jesus and Rolim 2005; Peixoto et al. 2008). The forests of Muçununga, where the collections of this study were carried out, usually form enclaves inside the Mata Alta and occur on sandy deposits, with a canopy of about $10 \mathrm{~m}$ in height and great penetration of light in the understory (Peixoto et al. 2008). The native field consists of a physiognomy varying from herbaceous to shrubby and also occurs on sandy soils, forming enclaves in Mata Alta and Muçununga (Araújo et al. 2008). There are permanently flooded areas, or floodplains, they have physiognomy ranging from herbaceous to shrub, with a canopy of about $12 \mathrm{~m}$ in height (Peixoto et al. 2008). The climate is characterized by a wet summer season between the months of December and February and a dry autumn-winter season between May and September separated by seasons of transition average and environmental variations for the behaviour of floral visitors should be considered (Oster and Wilson 1978; Richman et al. 2017) When observing the specimen of Serjania caracasana and the numerous floral visitors present throughout the day, this study sought to understand the strategy of nectar production of the plant and the foraging behaviour of insects. It was based as an initial hypothesis the dependence of the greater production of the nectar in the greater wealth of visiting species.

\section{(Engel and Martins 2005).}

\subsection{Characteristic of the plant species:} The genus Serjania Mill., one of the main groups of the Sapindaceae family, is represented by about 150 genera and 2000 species, distributed in tropical and subtropical regions (Souza and Lorenzi 2005). Among Serjania species, $S$. caracasana (Fig. 1, Fig. 2) is characterized as a climbing species, and it is considered one of the most representative in terms of species of scaly Angiosperms (Gentry, 1991). This species presents a stem composed of a central cylinder and 8 smaller peripherals with octagonal marrow. It has glabrous branches and rarely pubertal. Its leaves are biternate or foliolate with hardening in the abaxial face and the scorpioides inflorescences with small floral buds (Sprengel-Lima, Alves Rezende 2013). Several species of Serjania present important ethnopharmacological use, in the making of handicrafts, landscaping and even in beekeeping production (Guarim-Neto et al. 2000). The dominance of Serjania pollen in honey samples has already been verified. This shows its importance in the production of honey and nectar source (Freitas and Silva 2006), where a large variety of species of social and solitary bees visit flowers of plants belonging to Serjania ( $S$. caracasana (Jacq.) Willd; S. glabrata Kunth; S. communis Camb; S. pernambucensis) (Martins et al. 2003).

3.3 Data collect: Considering the difficult of identifying real genets, eight ramets of $S$. 
caracasana growing in Mussunuga vegetation of the Vale Natural Reserve, in August 2016, were monitored with observation beginning at 7:00 am and ending at 15:00 pm, during 3 consecutive days. Before beginning a daily observation, 3 inflorescences of different ramets were protected with a bag to carry out the nectar collections. The day the temperature and the volume of nectar were taken hourly. The amount of nectar was withdrawn from 3 flowers with the aid of glass capillary. The capillaries with the volume of nectar were kept in a cooled environment for their conservation until the analysis. To calculate the volume of the nectar, each capillary was measured for the height of the amount of nectar and diameter by the image J program and afterwards the nectar was weighed in analytical balance. The frequencies of visits were counted by means of observations, setting up a visit every time the insect inoculated its oral device inside the flower. All species were photographed for later identification.

3.4 Data analysis: From the data obtained, the Margaleff Diversity Index and the amount of nectar were calculated according to the temperature and time of day. These data were submitted to the statistical test of simple linear regression by the SYSTAT program.

order of visits, wasps, bees, flies, moths and beetles (Fig. 3, fig. 4) of 8633 visits (Tab. 1).

During the observation period in the specimen of Serjania caracasana (Fig. 1, fig. 2), a total of 15 species were counted, followed in ascending
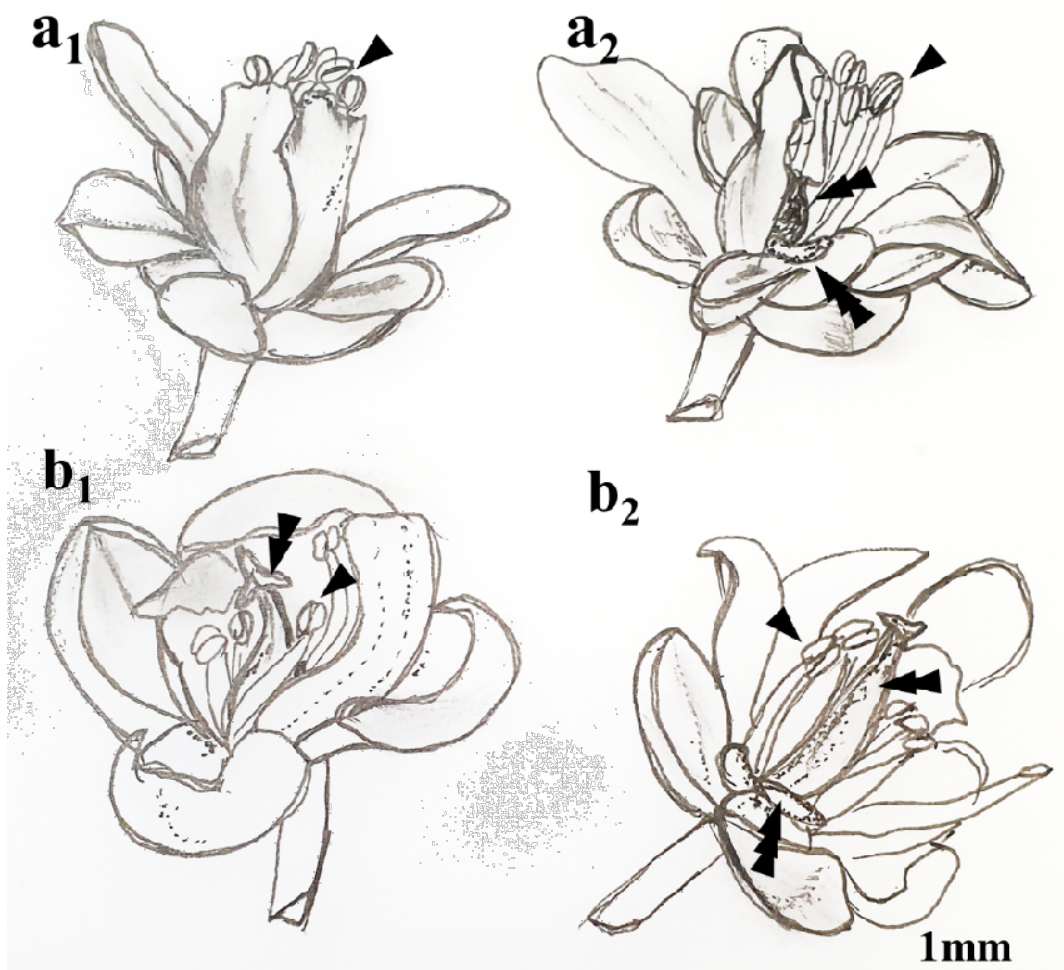

Figure 1: Serjania caracasana (Jacq.) Willd. a. Staminate flower. $\mathbf{a}_{1}$ : longitudinal view, showing the anthers (arrow) on the top of filaments. $\mathbf{a}_{2}$ : inside view showing the monadelphic androecium (arrow), the pistilode (double arrow) and the nectariferous disk (triple arrow). b: Pistilate flower. $\mathbf{b}_{1}$ : longitudinal view showing staminodes (arrow) and the gynoecium (double arrow). $\mathbf{b}_{2}$ : inside view showing the staminodes (arrow), the gynoecium (double arrow) and the nectariferous disk (triple arrow). 


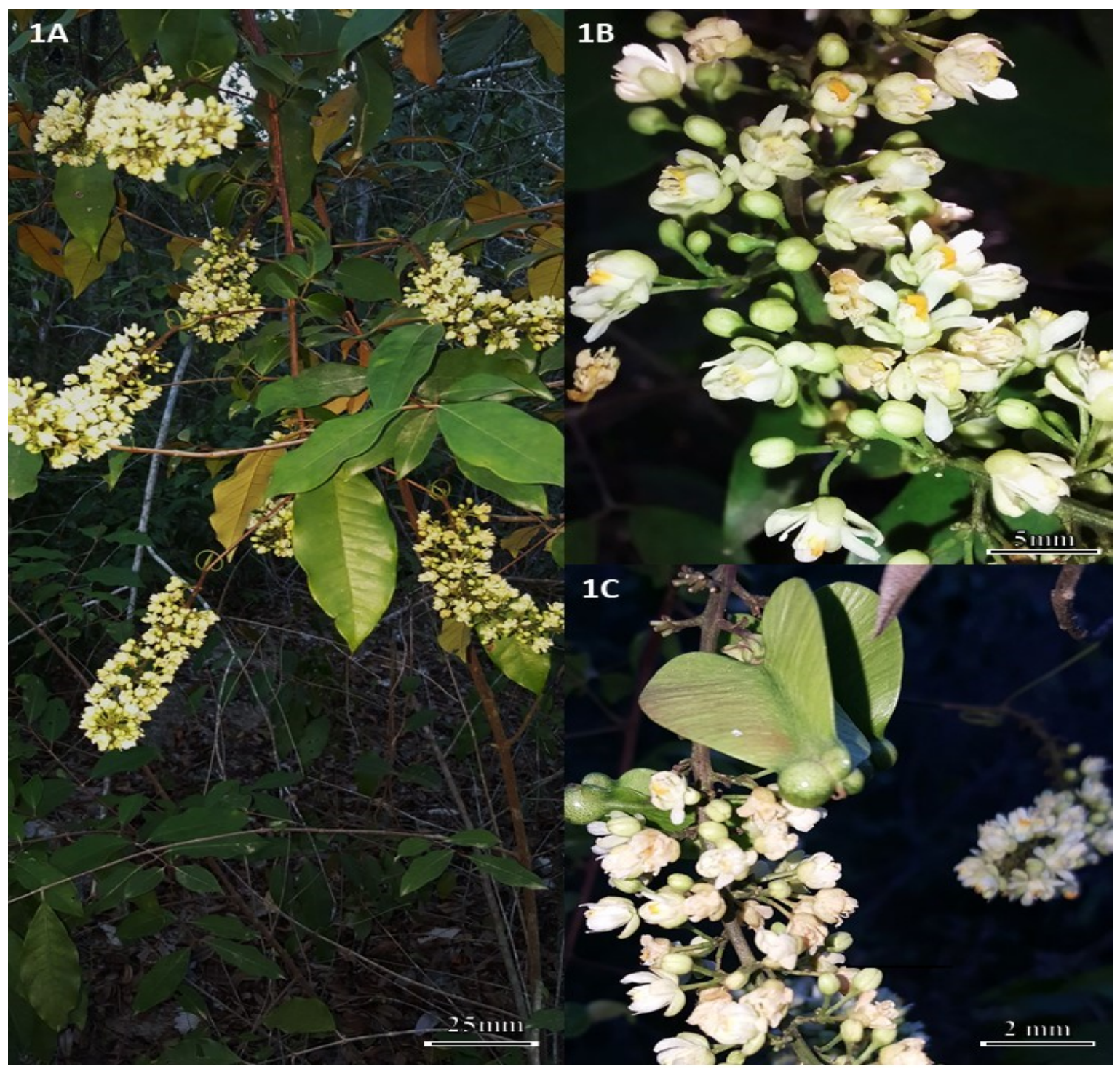

Figure 2: Exemplary of Serjania caracasana. 1A: information on vegetative characters such as branches, foliolate leaves and inflorescences; 1B: tiny flowers and flower buds of an inflorescence; 1C: fruit. 


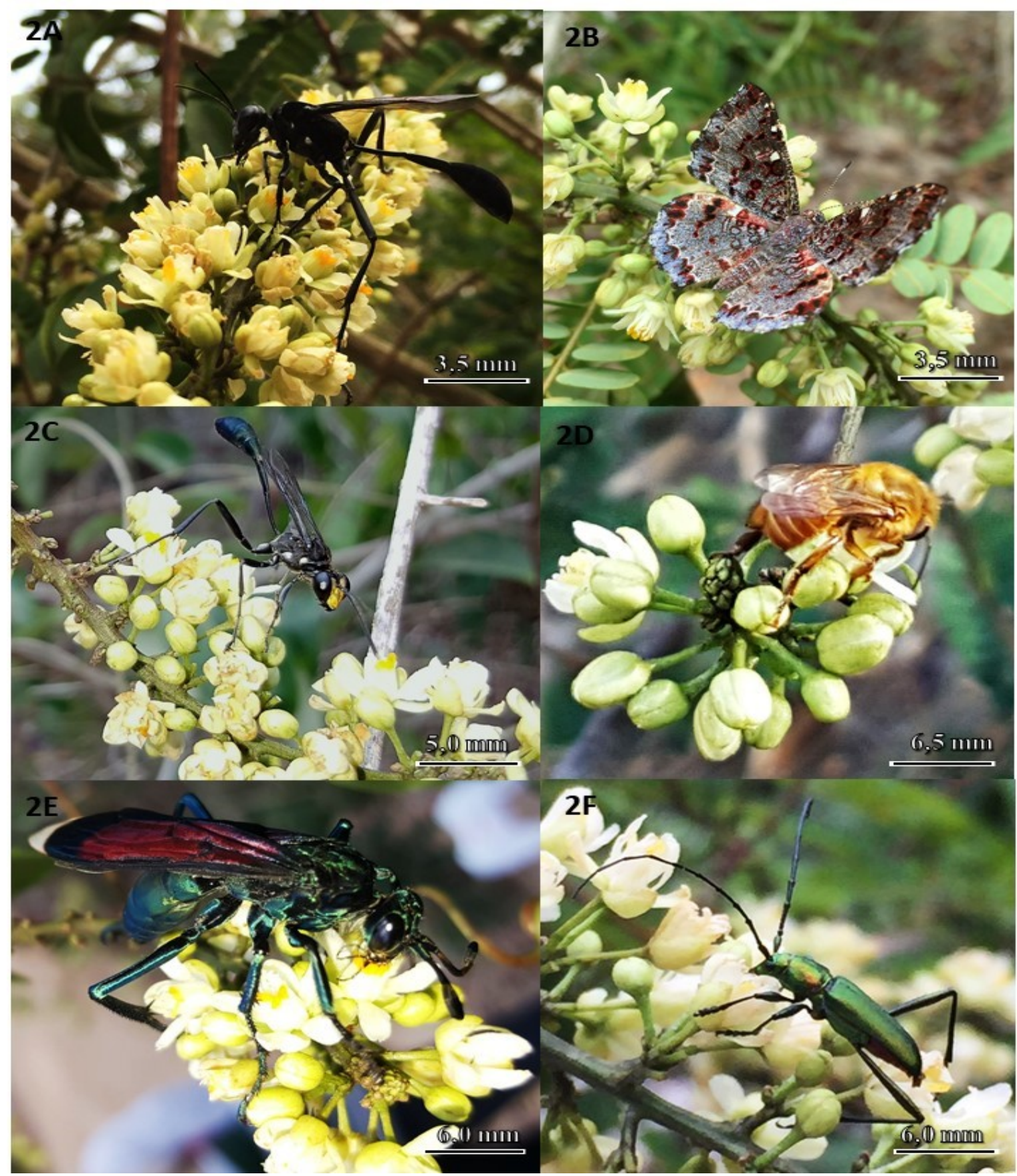

Figure 3: Some floral visitors to Serjania caracasana. 1A: Eremnophila binodis (Fabricius, 1798); 2B: Calephelis braziliensis (McAlpine, 1971); 2C: Eremnopbila eximia (Lepeletier, 1845); 2D: Melipona rufiventris (Lepeltier, 1836); 2E: Pepsis egregia (Mocsáry, 1885); 2F: Species of the family Cerambycidae. 


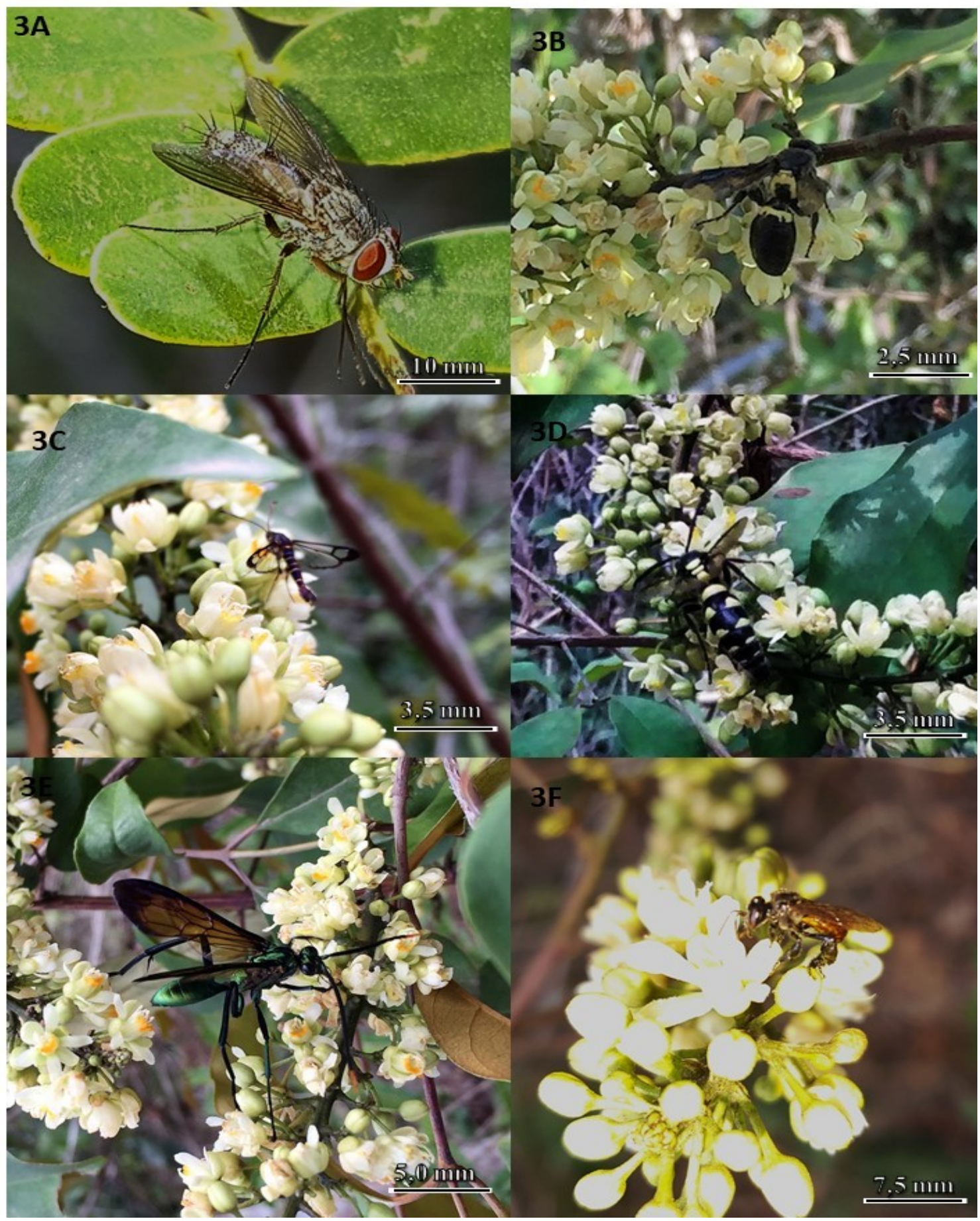

Figure 4: Some floral visitors to Serjania caracasana. 3A: Delia platura (Meigen, 1826); 3B: Euodynerus bidalgo (de Saussure, 1857); 3C: Carmenta bassiformis (Walker, 1856); 3D: Polistes versicolor (Olivier, 1791); 3E: Sphex nitidiventris (Spinola, 1851); 3F: Tetragonisca angustula (Latreille, 1811). 


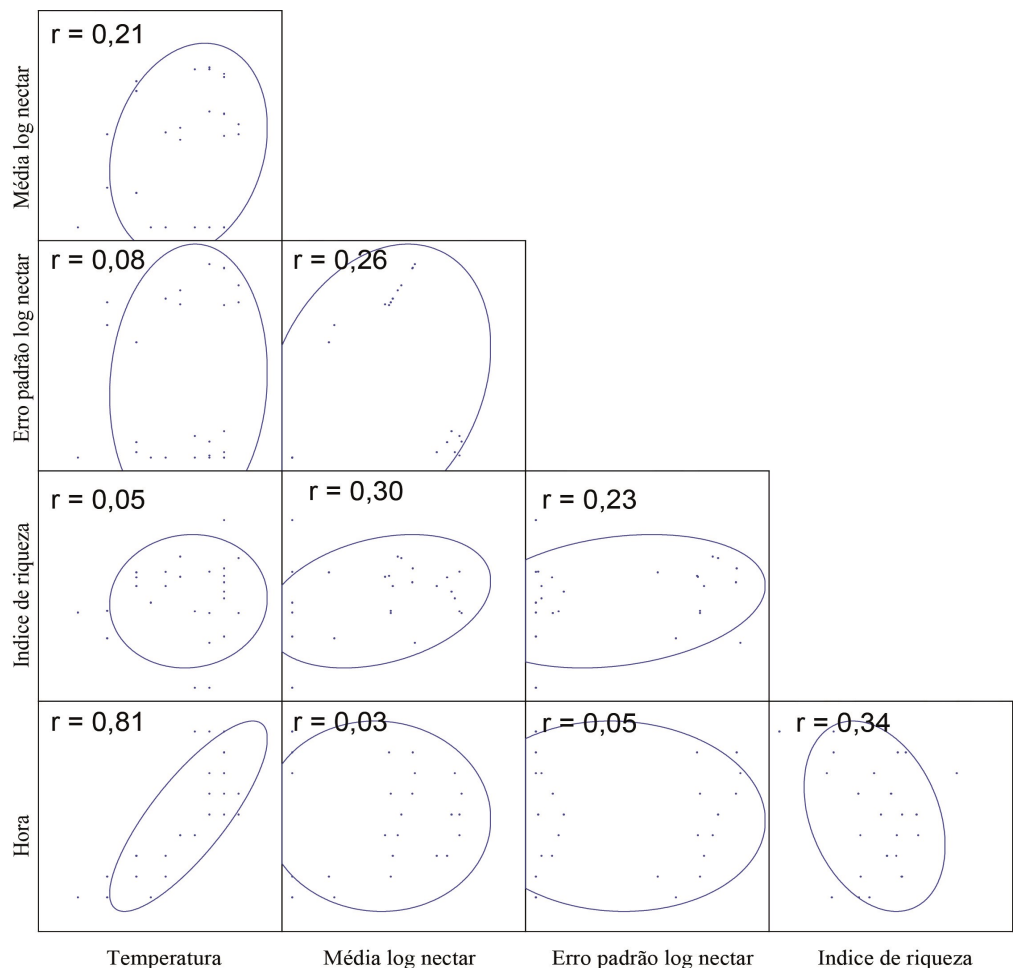

Figure 5: Correlation diagram of nectar in relation to temperature, day time and species richness of floral visitors.

During the observation period, during the first and second day the temperature ranged from 17 ${ }^{\circ} \mathrm{C}$ to $7: 00$ am to $27^{\circ} \mathrm{C}$ to $15 \mathrm{pm}$ and on the third day ranged from $22^{\circ} \mathrm{C}$ to $27^{\circ} \mathrm{C}$. The nectar volume of the 3 flowers collected at each hour varied throughout the day and did not present progressively nor equivalent to the same schedules of the other evaluated days, with some flowers with absence or without

\section{DISCUSSION}

Different from the observations that generally support the expectations of optimal foraging (Pyke 2010 and Pyke 2016), foraging can also be presented as "risk-sensitive." In this behaviour, the animals exploit two resource units even under varying conditions (Caraco 1980). The unpredictable pattern of nectar production presented by Serjania caracasana and the floral visitors' activity in this study may be characterized by the risk-prone foraging strategy (Oster and Wilson, 1978; Caraco 1980), which exploits a resource that has variation. significant volume of nectar. Regarding the production of nectar, there was no predictability in the activity of floral visitors based on resource availability, time of day and temperature (Fig. 5). The values of temperature and nectar on the activity of floral visitors presented a negative and statistically nonsignificant correlation ( $p>0.05)$ (Tab. 2).

There is still room for debate and $r$ researcher so as to reach a consensus on whether pollinators are more typically risk-averse or riskprone. Studies suggest that most pollinators should avoid risk-prone foraging strategies (Real 1980; Caraco 1981), but when other factors such as scarcity of resources or reproductive season are involved, some animals may exhibit this behaviour (Cartar 1990; Real and Caraco 1986). This information is relevant, because during the investigation period, the study region went through a long period of 
drought, which may explain the activity of the visitors that did not obey the optimal foraging theory, showing no correlation between any of the evaluated constants. However behavioural ecologists have explored several new dimensions of compensation for this type of decision making (Ings and Chittka 2008). One of the explanations that some authors have been exposing is research on animal "personality" (Burns 2005; Burns and Dyer 2008; Muller and Chittka 2008). It is true that there is a variety of flower species available that can vary in the availability of nectar according to time (Real 1981). In a study with forage bees, they show coexisting strategies, where some individuals place more emphasis on accuracy and others on speed that may vary depending on individual differences (Chittka et al. 2003). This variety may be essential for the survival of the colonies in that it allows the colony to respond flexibly to environmental variation. Thus, spatial and temporal heterogeneity in the environment can play an important role in maintaining diversity (Muller and Chittka 2008). Bees and wasps are insects that participate in the various processes of interactions between plants and animals and have great importance in plant pollination (Clemente et al. 2012). In the plant species focus of this study, floral visitors have short mouthparts such as butterflies, beetles, bees and wasps. The wasps, already described as generalist pollinators, were represented in the observations of this study with the highest frequency of visits to the Serjania caracasana specimen. Pollination by

\section{REFERENCES}

Araujo, D. S. D., Pereira, O. J., \& Peixoto, A. L. 1900. Campos nativos at the Linhares forest reserve, Espírito Santo, Brazil. Memoirs of the New York Botanical Garden. 371 pp.

Aleixo, K.P., Delgado Assad, A.L., de Souza, S. and Lange Canhos, D.A. 2017. Sistemas de informação como recurso para a conservação das abelhas no Brasil. Brasil. 4 pp. these species is associated with small flowers, such as those of Serjania caracasana or those with few morphological restrictions (Pereira 2014). Most of the generalist interactions of this group of plants refer to wasps (Santos et al. 2010). However, the fact that their flowers are visited by several orders of insects does not mean that all of them can act as pollinators. This leads us to the necessity of other studies for any inference about the performance of these species as pollinators of Serjania caracasana. Some investigations of the use of Vespidae species have already gained interest in biological control of agricultural pests (Marques et al. 1993 and Picanço 2014). It is probable that this plant can be object of study in an integrated pest management program, as a possible supplier of food to the species of interest as a biological control agent of pests. Research such as this can help to generate knowledge in activities such as beekeeping and meliponic culture that can contribute to biodiversity conservation and provide sustainability in rural communities (Aleixo 2017). Thus, we can suggest that Serjania caracasana, because it presents an inconsistent volume of nectar with variation of the availability of the resource and the frequency of the floral visitors, can be a species with great potential to understanding the theory of the forage susceptible to the risk in relation to its reproductive success. It can contribute to the conservation of biodiversity and provide sustainability in rural communities.

Burns J.G. 2005. Impulsive bees forage better: the advantage of quick, sometimes inaccurate foraging decisions. Animal Behaviour,70: 1-5.

Burns J.G. \& Dyer A.G. 2008. Diversity of speed-accuracy strategies benefits social insects Current Biology, 18: 953-954.

Cartar R V., Lawrence M 1990. Dill Why are bumble bees risk-sensitive foragers? Behaviour Ecology Sociobiology, 
26:121-127.

Chittka L., Dyer, A.G., Bock F. A. 2003. DornhausBees trade off foraging speed for accuracy. Nature, 424: 388.

Caraco T., Martindale S., Whittam T. S. 1980. An empirical demonstration of risksensitive foraging preferences. Animal Behaviour, 28:820-830.

Clemente, M. A., Lange, D., Del-Claro, K., Prezoto, F., Campos, N. R., \& Barbosa, B. C. 2012. Flower-visiting social wasps and plants interaction: Network pattern and environmental complexity. Psyche: A Journal of Entomology.

Engel, V. L., \& Martins, F. R. 2005. Reproductive phenology of Atlantic forest tree species in Brazil: an eleven year study. Tropical ecology, 46: 1-16.

Freitas, B. M. \& Silva, E. M. S. 2006. Potencial apícola da Vegetação do semiárido Brasileiro. In: Giulietti, A. M. (Ed.) Apium Plantae, 3: 19-32.

Guarim-Neto G., Santanas S. R., Silva J.V.B. 2000. Notas Etnobotânicas de Espécies de Sapindaceae Jussieu. Acta Botânica Brasílica, 14: 327-334.

Gentry A.H. 1991. The distribution an devolution of climbing plants. In, Putz F E,

Heil, M. 2011. Nectar: generation, regulation and ecological functions. Trends Plant Sci. 16: 19-200.

Hodges, C.M. \& Wolf, L.L. 1981. Optimal foraging in bumblebees - why is nectar left behind in flowers? Behavioral Ecology and Sociobiology, 9: 41-44.

Jesus, R. D., \& Rolim, S. G. 2005. Fitossociologia da Mata Atlântica de tabuleiro. Boletim Técnico da Sociedade de Investigações Florestais, 19: 1-149.

Lange D., Dáttilo W., Del-Claro K. 2013. Influence of extrafloral nectary phenology on ant-plant mutualistic networks in a neotropical savanna. Ecological Entomology, 38: 463-469.

Marques, O.M., Carvalho, C.A.L. de \& Costa, J.M. 1993. Levantamento das espécies de vespas sociais (Hymenoptera, Vespidae) no Município de Cruz das Almas - Estado da Bahia. Insecta, 2: 1 9.

Martins C.F., Moura A.C., Barbosa M.R. 2003. Bee plants and relative abundance of corbiculate Apidae species in a Brazilian caatinga area. Revista Nordestina de Biologia, 17: 63-74.

Mooney H A (Ed.). The Biology of vines. Cambridge University Press, Cambridge, 3-49.

Ings T.C. \& Chittka L. 2008. Speed accuracy tradeoffs and false alarms in bee responses to cryptic predators. Current Biology, 18: 1520-1524.

Muller, H., \& Chittka, L. (2008). Animal personalities: the advantage of diversity. Current Biology, 18: 961-963.

Oster G.F. \& Wilson E.O. 1978. Caste and ecology in the social insects. Princeton, Princeton University Press. 277 pp.

Peixoto, A. L., Silva, I. M., Pereira, O. J., Simonelli, M., Jesus, R. D., \& Rolim, S. G. 2008. Tabuleiro forests north of the rio Doce: their representation in the Vale do Rio Doce Natural Reserve, Espírito Santo, Brazil. Memoirs of the New York Botanical Garden, 100: 319350.

Picanço, M. C. 2014. Natural Biological Control of Diaphania spp. (Lepidoptera: Crambidae) by Social Wasps. Sociobiology, 59: 561-571.

Sprengel-Lima, C., \& Alves Rezende, A. 2013. Sapindaceae do noroeste paulista: lista de espécies e chave de identificação baseada em caracteres vegetativos. Biota Neotropica, 13: 2.

Pereira, R. A. S. 2014. Polinização por vespas. Biologia da polinização. Editora Projeto Cultural. 527 pp.

Pyke, G.H. 2010. Optimal foraging and plantpollinator coevolution. In Encyclopedia of Animal Behavior (Breed, M.D. and Moore, J., eds). Academic Press. 596 pp. 
Pyke, G. H. 2016. Floral nectar: Pollinator attraction or manipulation? Trends in ecology \& evolution, 31: 339-341.

Rathcke B.J. 1992. Nectar distribution, pollinator behaviour and plant reproductive success. (eds. Hunter M D, Ohgushi T, Price P W), Academic Press. 113 pp.

Real L. \& Caraco T. 1986. Risk and Foragingin Stochasticenvironments. Annual Review of Ecology and Systematics, 17: 371-90.

Real L.A. 1981. Uncertainty and pollinatorplant interactions: the foraging behaviour of bees and wasps on artificial flowers. Ecology, 62: 20-26.

Richman, S. K., Irwin, R. E., Bronstein, J.L. 2017. Foraging strategy predicts foraging economy in a facultative secondary nectar robber. Oikos, 126: $1250-1257$.

Ricklefs, R E (2009) Adaptação à vida em ambientes variantes. A economia da natureza. Guanabara Koogan. 168 pp.

Santos, G.M.D., Aguiar, C.M.L., Mello, M.A.R. 2010. Flower-visiting guild associated with tehe Caatinga Flora: trophic interaction networks formed by social bees and social wasp with plants. Apidologie, 41: 466-475.
Sazima M, Sazima I, Buzato S. 1994. Nectar by day and night: Siphocampylus sulfureus (Lobeliaceae) pollinated by hummingbirds and bats. Plant Systematics and Evolution, 191: 237 246.

Souza V.C. \& Lrenzi, H. 2005. Botânica Sistemática: Guia ilustrado para identificação das famílias de angiospermas da flora Brasileira. Baseado em APG II. Nova Odessa, SP: Instituto Plantarum. 640 pp.

Vicentini A, Fischer E 1999. Pollination of Moronobea coccinea (Clusiaceae) by the Golden-Winged Parakeet in Central Amazon. Biotropica, 31: 692-696.

Vieira C.G.H., Marchini L.C., Souza B.A., Moreti A.D.C. 2008. Fontes florais usadas por abelhas (Hymenoptera, Apoidea) em área de cerrado no município de Cassilândia. Revista Ciência e Agrotecnologia, 32: 14541460.

Zimmerman M. \& Pike G.H. 1988. Experimental manipulations of Polemonium foliosissimum: effects on subsequent nectar production, seed production, and growth. Journal of Ecology, 76: 777-789.

Table 1. Species and family of insects observed visiting flowers of Serjania caracasana during their flowering period.

\begin{tabular}{l|l} 
Species / family & Number of visits \\
\hline Sphex pensylvanicus (Linnaeus,1763) & 2488 \\
\hline Sphex nitidiventris (Spinola, 1851) & 1110 \\
\hline Eremnophila binodis (Fabricius, 1798) & 1379 \\
\hline Pepsis egregia (Mocsáry, 1885) & 922 \\
\hline Tetragonisca angustula (Latreille, 1811) & 992 \\
\hline Eremnophila eximia (Lepeletier, 1845) & 447 \\
\hline Polistes versicolor (Olivier, 1791) & 382 \\
\hline Chrysomya megacephala (Fabricius, 1794) & 311 \\
\hline Calephelis braziliensis (McAlpine, 1971) & 170 \\
\hline Delia platura (Meigen, 1826) & 159 \\
\hline Euodynerus hidalgo (de Saussure, 1857) & 102 \\
\hline Cerambycidae & 64
\end{tabular}


\begin{tabular}{l|l} 
Melipona rufiventris (Lepeltier, 1836) & 54
\end{tabular}

\begin{tabular}{l|l}
\hline Curculionidae & 27 \\
\hline Carmenta bassiformis (Walker, 1856) & 26
\end{tabular}

Table 2: Linear regression analysis of the activity of the visiting insects as a function of nectar availability.

\begin{tabular}{l|l|l|l|}
\hline Constant & F-ratio & Valor-p & degree of freedom \\
\hline Temperature & 1.150 & 0.295 & 22 \\
\hline Nectar (Maximum) & 0.009 & 0.924 & 22 \\
\hline Néctar (Average) & 0.079 & 0.781 & 22 \\
\hline Néctar (SE) & 0.006 & 0.940 & 22 \\
\hline
\end{tabular}

SE: stand 